\title{
Maternal inheritance on reproductive traits in Brangus-Ibagé cattle
}

\author{
Herança materna em caracteres reprodutivos em bovinos brangus-ibagé
}

\author{
Luis Ernani Henkes ${ }^{1}$ Magda Vieira Benavides ${ }^{2}$ João Francisco Coelho Oliveira ${ }^{3}$ \\ José Carlos Ferrugem Moraes ${ }^{4}$ and Tania Azevedo Weimer ${ }^{5}$
}

\section{ABSTRACT}

Cytoplasmic inheritance influence on reproductive traits was investigated in the Brangus-Ibagé cattle (3/8 Nelore x 5/8 Aberdeen Angus). Additive genetic effects were responsible for $12 \% \pm 11 \%$ of phenotypic variation observed in first calving interval, but their contribution dropped to zero when all calving intervals $(C I)$ were considered. The heritability estimate for age at first calving ( $A F C$, in days) was $0.19 \pm 0.09$. Mitochondrial lineage (MIT) had negligible effects on phenotypic variances of calving interval $(0.0 \pm 0.02)$, calf birth weight $(0.0 \pm 0.01)$, and cow weight at calving $(0.0 \pm 0.01)$. However, for the age at first calving, MIT accounted for $0.15 \pm 0.07$ of total variation. Cow weight at calving had a significant linear effect on CI and AFC. Three D-loop mtDNA mutations significantly affected either calving interval $(T \rightarrow C$ at sites 16,113 and 16,119) or calf birth weight $(T \rightarrow C$ at site 16,113). The $C$ variants had decreased $C I$ ( 29 and 32 days, respectively) and increased calf weight $(0.6 \mathrm{~kg})$. Although the effects were small, direct selection for these mutation-carrier cows might improve the reproductive and developmental performance in this herd.

Key words: $m t D N A$, maternal inheritance, calving interval.

\section{RESUMO}

A influência da herança citoplasmática sobre características reprodutivas foi investigada em bovinos Brangus-Ibagé (3/8 Nelore x 5/8 Aberdeen Angus). Os efeitos genéticos aditivos foram responsáveis por $12 \% \pm 11 \%$ da variação fenotípica observada no primeiro intervalo entre partos, mas esta contribuição decresceu para zero quando todos os intervalos entre partos (IEP) foram considerados. A herdabilidade da idade para o primeiro parto (IPP, em dias) foi estimada em 0,19 $\pm 0,09$. A linhagem mitocondrial teve um efeito negligenciável na variância fenotípica do intervalo entre partos $(0,0 \pm 0,02)$, peso do terneiro ao nascer $(0,0 \pm$ $0,01)$ e peso da vaca ao parto $(0,0 \pm 0,01)$. No entanto, para a idade ao primeiro parto, a linhagem mitocondrial contribuiu com 0,15 $\pm 0,07$ da variação total. $O$ peso da vaca ao parto teve efeito linear significante em IEP e IPP. Três mutações na região D-loop do mtDNA afetaram significantemente o IEP $(T \rightarrow C$ nos sítios 16.113 e 16.119) ou o peso do terneiro ao nascer $(T \rightarrow C$ no sítio 16.113). As variantes $C$ diminuíram o intervalo entre partos (29 e 32 dias, respectivamente) $e$ aumentaram o peso do terneiro (0,6 kg). Embora os efeitos sejam pequenos, a seleção de fêmeas portadoras dessas mutações poderia melhorar o desempenho reprodutivo $e$ o desenvolvimento deste rebanho.

Palavras-chave: $m t D N A$, herança materna, intervalo de partos.

\section{INTRODUCTION}

Dams can influence their progeny phenotypes through nuclear maternal genetic effects, permanent environmental maternal effects, and cytoplasmic inheritance (BELL et al., 1985). Many

${ }^{1}$ Veterinarian, DSc, Universidade Federal do Rio Grande do Sul (UFRGS), Porto Alegre, RS, Brazil.

${ }^{2}$ Graduated in Animal Sciences, PhD, Empresa Brasileira de Pesquisa Agropecuária, EMBRAPA/ Pecuária Sul, Bagé, RS, Brazil

${ }^{3}$ Veterinarian, DSc, Universidade Federal de Santa Maria, Santa Maria, RS, Brazil

${ }^{4}$ Veterinarian, DSc, Empresa Brasileira de Pesquisa Agropecuária, EMBRAPA/Pecuária Sul, Bagé, RS, Brazil

${ }^{5}$ Geneticist, DSc, UFRGS, Porto Alegre, RS and Universidade Luterana do Brazil Canoas, RS. Depto de Genética, UFRGS, CP 15053, 91501-970, Porto Alegre, RS, Brazil. Phone nº 55513316 6720; fax nº 55513316 7311. E-mail: weimer@ufrgs.br. Corresponding author 
studies have focused on cytoplasmic effects on economic traits in dairy cattle (BELL et al., 1985; BOETTCHER et al., 1996). The first studies highlighted the influence of cytoplasmic lineages on production traits. Later, analyses including polymorphisms on mitochondrial DNA (mtDNA) suggested their effects on physiological functions (SMITH \& ALCIVAR, 1993) and on economic traits in dairy and beef cattle (SCHUTZ et al., 1994; MANNEN et al., 1998).

Mitochondria are the only source of DNA in the cytoplasm and the site of aerobic respiration, playing a central role in energy provision to eukaryotic cells. Almost $90 \%$ of the ATP of mammals is produced in mitochondria. The structure and gene organisation are highly conserved in mammalian mtDNA (WOLSTENHOLME, 1992). Nonetheless, the control region or displacement loop (D-loop) is extremely variable and, despite its functional importance, has a rate of nucleotide substitution 5 - 10 times higher than that of nuclear DNA. This feature has been widely used to trace mammalian phylogenies (TROY et al., 2001, MAGEE et al., 2002).

The aim of this study was to verify the influence of cytoplasmic and mitochondrial lineages on reproductive traits in a beef cattle herd. A further objective was to determine the association of specific polymorphisms in mtDNA with reproductive performance.

\section{MATERIAL AND METHODS}

Records from a Brangus-Ibagé herd (3/8 Nelore x 5/8 Aberdeen Angus composite breed) from the Southern Brazilian Livestock Research Centre (EMBRAPA-Pecuária Sul, Bagé, RS, Brazil, 54²3'W and $30^{\circ} 47^{\prime} \mathrm{S}$ ) were used in this study. This herd resulted from the crossing of Aberdeen Angus cows and Nelore bulls and has been selected only for adult male body weight and large frame structure, since its formation in 1945. Selection for reproductive performance has not been attempted so far. All animals have been managed exclusively on native pasture under extensive conditions (OLIVEIRA et al., 1998).

Mitochondrial lineages were established by tracing the ancestry of cows to the founder females in the herd. Production records of 1577 females born between 1953 and 1996 were analysed. Parity ranged from 1 to 13 with an average of 3.1 calvings per female. There were 151 different mitochondrial lineages. Sequence information from a 277 nucleotide fragment from the D-loop mtDNA was available for 49 of these mitochondrial lineages (Henkes, unpublished data). Of the 18 haplotypes found in that study, 16 were used in this analysis.

Five reproductive traits were analysed: first calving interval (CI1) in days, calving interval (CI) in days (average of all CI information), age at first calving (AFC) in days, calf birth weight (CBW) in $\mathrm{kg}$ and cow weight at calving (CWC) in $\mathrm{kg}$. All females were first mated at around 3 years of age. The number of observations varied according to the analyses performed due to missing observations.

Data were analysed using the General Linear Models (GLM) of SAS V6 (SAS/STAT, 1990) to determine significant fixed effects. Cow weight at calving (CWC) was fitted in the model as a covariate for CI1, CI and AFC. Sire (s) and mitochondrial lineage (mit) were included as random effects as suggested by TESS \& MACNEIL (1994) and RORATO et al. (1999), according to equations:

$\mathrm{y}_{i j k l m}=\mu+\mathrm{yob}_{i}+\mathrm{po}_{j}+\mathrm{yob}^{*} \mathrm{po}_{i j}+\beta \mathrm{CWC}_{i j k l m}+\mathrm{s}_{k}+\mathrm{mit}_{l}$ $+\mathrm{e}_{i j k l m}$ $\mathrm{y}_{i j k l m}=\mu+\mathrm{yob}_{i}+\mathrm{po}_{j}+\mathrm{yob}^{*} \mathrm{po}_{i j}+\mathrm{s}_{k}+\mathrm{mit}_{l}+$ $\mathrm{e}_{i j k l m}$

where, $\mathrm{y}_{i j k l m}$ is the CI1, CI or AFC phenotype (model 1a) or CWC and CBW phenotype (model $1 b$ ) of the $m^{\text {th }}$ individual; $m$ is the effect of a population mean; $\mathrm{yob}_{i}$ is the effect of the $\mathrm{i}^{\text {th }}$ year of birth; $\mathrm{po}_{j}$ is the effect of the $\mathrm{j}^{\text {th }}$ parity order; yob* $\mathrm{po}_{i j}$ is the effect of the year of birth $\mathrm{x}$ parity interaction; $\beta$ is the regression coefficient for cow weight at calving; $\mathrm{CWC}_{i j k l m}$ is the effect cow weight at calving; $\mathrm{s}_{k}$ is the additive effect of the $\mathrm{k}^{\text {th }}$ sire; mit $_{l}$ is the effect of the $1^{\text {th }}$ mitochondrial lineage; and $\mathrm{e}_{i j k l m}$ is the residual effect associated with $\mathrm{y}_{i j k l m}$ observation.

Only significant fixed effects $(\mathrm{p}<0.05$, at least) found in (1) were included in the models for estimating variance components (year of birth, parity order, and yob x po interaction).

For the genetic estimates and variance component analyses the contributions of the additive genetic, maternal genetic and direct permanent environmental, and residual effects to total phenotypic variance for CI1, CI, AFC, CWC, and CBW were calculated using Restricted Maximum Likelihood (REML) with an average information algorithm and fitting various animal models to the data. The Average Information Restricted Maximum Likelihood (AIREML) statistical package (JOHNSON \& THOMPSON, 1995) was used for analyses.

(a) The equation including the maternal (nuclear, cytoplasmic and in-uterus environmental) effects was:

$\mathrm{y}=\mathrm{X} \beta+\mathrm{Z}_{\mathrm{d}} \mathrm{u}+\mathrm{Z}_{\mathrm{m}} \mathrm{m}+\mathrm{Z}_{\mathrm{p}} \mathrm{p}+\mathrm{e}$ 
where, $\mathrm{y}$ is the vector of CI, CI1, AFC,CWC or CBW observations; $\beta$ is the vector for fixed effects (yob, po, and yob*po interation); $\mathrm{u}$ is the vector of random additive genetic effects; $m$ is the vector of maternal (genetic and in-uterus environmental effects); $p$ is the vector of direct permanent environment effect, and $\mathbf{e}$ is the vector of random residual effects, and $X, Z_{d}, Z_{m}$, and $Z_{p}$ are incidence matrices relating records to fixed, additive genetic, maternal and direct permanent environmental effects, respectively.

In model 2 dam was fitted as a second animal effect with covariance matrix uncorrelated with direct additive effect.

(b) The equation for the mitochondrial lineage effects was:

$\mathrm{y}=\mathrm{X} \beta+\mathrm{Z}_{\mathrm{d}} \mathrm{u}+\mathrm{Z}_{\mathrm{m}} \mathrm{m}+\mathrm{Z}_{\mathrm{t}} \mathrm{mit}+\mathrm{Z}_{\mathrm{p}} \mathrm{p}+\mathrm{e}$

where, $y$ is the vector of CI1,CI,AFC,CBW or CWC observations; $\beta$ is the vector of fixed effects (yob, po, and yob*po interation); $\mathrm{u}$ is the vector of random additive genetic effects; $m$ is the vector of maternal (nuclear and in-uterus environmental effects); mit is the vector of mitochondrial lineage effect (which groups females with the same mitochondrial haplotypes), $\mathrm{p}$ is the vector of direct permanent environmental effects, and $e$ is the vector of random residual effects, and $\mathrm{X}, \mathrm{Z}_{\mathrm{d}} \mathrm{Z}_{\mathrm{m}} \mathrm{Z}_{\mathrm{t}}$, and $Z_{p}$ are incidence matrices relating records to fixed, additive genetic, maternal, mitochondrial lineage, and direct permanent environmental effects, respectively.

(c) Analyses of nucleotide substitution effects: Repeated measurements analysis of variance, by using a sire model, was used to compare trait means for groups of animals with and without specific nucleotide substitution. Model equations 4 and 5 were used for the studied traits.

$\mathrm{y}_{i j k l m}=\mu+\mathrm{yob}_{i}+\mathrm{s}_{j}+\mathrm{sub}_{k}+\mathrm{b}_{i j k}+\mathrm{r}_{l}+\mathrm{yob}_{i} * \mathrm{r}_{l}+\mathrm{s}_{j} * \mathrm{r}_{l}+$ $\operatorname{sub}_{k} * \mathrm{r}_{l}+\mathrm{e}_{i j k l m}$

$\mathrm{y}_{i j k l}=\mu+\mathrm{yob}_{i}+\mathrm{s}_{j}+\mathrm{sub}_{k}+\mathrm{e}_{i j k l}$

where, $\mathrm{y}_{i j k l m}$ is the $\mathrm{CI}$ or $\mathrm{CBW}$ or CWC observation of the $\mathrm{m}^{\text {th }}$ individual (Equation 4) and $\mathrm{y}_{i j k l}$ is the AFC observation of of the $1^{\text {th }}$ individual (Equation5); $\mu$ is the effect of population mean; yob $_{i}$ is the effect of $\mathrm{i}^{\text {th }}$ year of birth; $\mathrm{s}_{j}$ is the random effect of $\mathrm{j}^{\text {th }}$ sire; $\mathrm{sub}_{k}$ is the random effect of $\mathrm{k}^{\text {th }}$ nucleotide substitution, $\mathrm{b}_{i j k}$ is the between-subject error term, $\mathrm{r}_{l}$ is the effect of $1^{\text {th }}$ repeated measurements of each trait, yob $_{i} * \mathrm{r}_{l}$ is the effect yob and $\mathrm{r}$ interaction, $\mathrm{s}_{j} * \mathrm{r}_{l}$ is the effect of the sire(s) and $r$ interaction, $\operatorname{sub}_{j}{ }^{*} r_{l}$ is the effect of the nucleotide substitution and $r$ interaction, and $\mathrm{e}_{i j k l m}$ and $\mathrm{e}_{i j k l}$ are the within-subject error term.

\section{RESULTS}

Table 1 summarises the descriptive statistics and genetic parameters for the traits. Analysis of variance showed that parity, year of birth, and the interaction between parity and year of birth were significant $(p<0.001)$ fixed effects.

The covariate cow weight at calving (CWC) was significant $(p<0.001)$ for both CI and AFC. Estimates of fractions of total phenotypic variance for additive genetic, maternal genetic and animal permanent environmental effects for CI1, CI, AFC, $\mathrm{CBW}$, and CWC are also shown in Table 1. The heritability estimates for CI and CBW were negligible. However, when only the first calving interval record of each cow (CI1) was considered, the direct heritability estimate was $0.12 \pm 0.11$. The estimate dropped dramatically when all intervals were considered. The maternal heritability $\left(\hat{\mathrm{h}}^{2} \mathrm{~m}\right)$ for the first CI was $0.04 \pm$ 0.08 but soon decreasing to $0.00 \pm 0.04$ when all intervals were analysed.

Mitochondrial lineage effects contributed little to total variance for all traits except for AFC $(0.15$ (0.07).

Significant effects of polymorphisms were not detected for AFC and CWC. However, some mtDNA nucleotide substitutions have a significant influence on CI and CBW (Table 2). Mutation T $\rightarrow \mathrm{C}$ at position 16,113 reduced average CI by 29 days. Likewise, $\mathrm{T} \rightarrow \mathrm{C}$ transition at position 16,119 reduced average CI by 32 days. A small but significant effect was observed for $\mathrm{CBW}$ where cows with a $\mathrm{T} \rightarrow \mathrm{C}$ transition at position 16,113 gave birth to calves 0.6 $\mathrm{kg}$ heavier than non-carriers.

\section{DISCUSSION}

In general, reproductive traits are known to have low heritability, with calving interval being one of the best examples. The low heritability estimate found in this herd is similar to an estimate of 0.16 reported for animals reared in native grassland livestock systems (PEREIRA, 1999). Even lower estimates (0.004 and 0.10 ) were presented in reviews by KOOTS et al. (1994) and KIRKPATRICK (1999). As the permanent environment has an extreme effect on $\mathrm{CI}$, the reduction of direct heritability estimate from 0.12 at the first CI to near zero when all CI were considered might have been due to the gradual increase of effects of non-genetic factors.

The heritability estimate for AFC $(0.19 \pm$ $0.09)$ was lower than the range (0.2 to 0.39$)$ reported for Bos taurus and Bos indicus cattle and their crosses 
Table 1 - Number of observations (n), means \pm standard error (se), number of cytoplasmic lines used in the analyses of variance: fractions of phenotypic variance $( \pm \mathrm{se})$ for direct heritability $\left(\hat{\mathrm{h}}^{2} \mathrm{~d}\right)$, maternal genetic $\left(\hat{\mathrm{h}}^{2} \mathrm{~m}\right)$ and direct permanent envir $\left(\hat{c}^{2}\right)$ effects, and mitochondrial effects (ME) for calving interval at first parity (CI1), calving interval at all parities (CI first calving (AFC), calf birth weight (CBW), and cow weight at calving (CWC) in a Brangus-Ibagé herd.

\begin{tabular}{llllllll}
\hline & $\mathrm{n}$ & Mean $\pm \mathrm{se}$ & Lines & $\left.\hat{\mathrm{h}}^{2} \mathrm{~d}\right)$ & $\hat{\mathrm{h}}^{2} \mathrm{~m}$ & $\mathrm{ME}$ & $\hat{\mathrm{c}}^{2}$ \\
\hline CI1 (days) & 1104 & $585.9 \pm 6.0$ & 151 & $0.12 \pm 0.11$ & $0.04 \pm 0.08$ & $0.00 \pm 0.03$ \\
CI (days) & 2399 & $524.5 \pm 4.0$ & 151 & $0.03 \pm 0.06$ & $0.00 \pm 0.04$ & $0.00 \pm 0.02$ & $0.22 \pm$ \\
AFC (days) & 662 & $1142.2 \pm 2.9$ & 151 & $0.19 \pm 0.09$ & $0.00 \pm 0.07$ & $0.15 \pm 0.07$ & $*$ \\
CBW (kg) & 3592 & $379.4 \pm 1.0$ & 151 & $0.00 \pm 0.03$ & $0.10 \pm 0.03$ & $0.00 \pm 0.01$ & $0.03 \pm$ \\
CWC (kg) & 3472 & $30.5 \pm 0.6$ & 151 & $0.23 \pm 0.04$ & $0.00 \pm 0.02$ & $0.00 \pm 0.01$ & $0.04 \pm$ \\
\hline
\end{tabular}

* Not applicable

(BARBOSA, 1991). MARTIN et al. (1992) reported an average heritability estimate of 0.40 for age at puberty, after reviewing studies of a wide variety of beef cattle breeds. In that review the Brangus breed (resulting, in this case, from the crossing between Aberdeen Angus and Brahman breeds) was reported to have the second highest age at puberty, ranging between the estimates of Aberdeen Angus and Brahman breeds. The heritability estimate for AFC and the variation observed for this trait indicates that the average AFC (1142.2 \pm 173.0 days $)$ in the BrangusIbagé herd studied might be improved by selection. On the other hand, the heritability due to mitochondrial lineages for AFC was $0.15 \pm 0.07$ and therefore cytoplasmic lines might be considered when selection is applied.

Cow weight at calving had a significant linear effect on CI and AFC. Younger age at first calving and shorter calving intervals are expected for dams with greater body weights. A medium/high nutritional status is essential to increase weight at calving since body condition at calving is one of the most important components influencing reproductive performance (OSORO \& WRIGHT 1992).

Two polymorphisms (at sites 16,113 and $16,119)$ were associated with a decrease in calving intervals in about 29 and 32 days, respectively. Despite the little magnitude of these findings a reduction of 30 days on CI could lead to a slight increase in lifetime production of the mutant dams, thus resulting in some economic gains for farmers.

At the time of this study, information for the effects of mtDNA mutations was available in literature only at positions 16,053, 16,057 and 16,147 (SCHUTZ et al., 1994). Mutations at positions 16,113 and 16,119 do not lie within any conserved position of the D-loop sequence (STEINBORN et al., 1998), being therefore difficult to explain their effect on reproductive performance. It cannot be excluded that these polymorphisms are in fact markers for differences in structural genes of mitochondria, which in turn have effects on reproductive traits. In further research more individuals need to be either sequenced or screened by single-strand conformation

Table 2 - mtDNA nucleotide $(n t)$ mutation effects on mean calving interval $(\mathrm{CI})$ and birth weight at calving $(\mathrm{CBW})$ in a Brangus-Ibagé herd.

\begin{tabular}{|c|c|c|c|c|c|c|c|}
\hline \multirow{3}{*}{ Position in D-loop } & \multirow{3}{*}{$\mathrm{nt}^{1}$} & \multicolumn{6}{|c|}{ Trait } \\
\hline & & \multicolumn{3}{|c|}{ CI (days) } & \multicolumn{3}{|c|}{ CBW (kg) } \\
\hline & & $\mathrm{n}^{1}$ & Means \pm s.e & $\mathrm{p}^{1}$ & $\mathrm{n}^{1}$ & Means \pm s.e & $\mathrm{p}^{1}$ \\
\hline \multirow[t]{2}{*}{16,113} & $\mathrm{~T} *$ & 202 & $545.7 \pm 7.0$ & 0.02 & 119 & $30.4 \pm 0.2$ & 0.04 \\
\hline & $\mathrm{C}$ & 98 & $517.0 \pm 10.1$ & & 76 & $31.0 \pm 0.3$ & \\
\hline \multirow[t]{2}{*}{16,119} & $\mathrm{~T} *$ & 231 & $543.6 \pm 6.6$ & 0.02 & & & \\
\hline & $\mathrm{C}$ & 69 & $512.0 \pm 12.0$ & & & & \\
\hline
\end{tabular}

The symbol * indicates reference sequence according to Anderson et al. (1982); ${ }^{1}$ nt: nucleotide; n: observed number; $\mathrm{p}=$ significance level. 
polymorphism in order to detect more lineages with these mutations. Selecting animals with these mutations and confirming that their reproductive performance is better than the non-carrier cows could allow the future use of these polymorphisms as a tool for marked assisted selection.

\section{CONCLUSIONS}

The results showed that progress could be made on reproduction by selection for first CI $\left(\hat{\mathrm{h}}^{2}=\right.$ $0.12 \pm 0.11)$ and $\mathrm{AFC}\left(\hat{\mathrm{h}}^{2}=0.19 \pm 0.09\right)$. Conversely, since the $h^{2}$ estimate of all calving intervals was near zero, other ways of improvement such as pasture and feeding supplements could be introduced in order to increase reproductive performance. Mitochondrial lineages did not account for variation in CI and therefore this type of inheritance appears to have no importance for genetic selection. Age at first calving was the only trait that appeared to have been affected by mitochondrial lineages $(0.15 \pm 0.07)$. Selection for animals with $\mathrm{T} \rightarrow \mathrm{C}$ transition at sites 16,113 and 16,119 on mtDNA could slightly improve the average $\mathrm{CI}$ of the herd. The effect of the 16,113 $\mathrm{C} \rightarrow \mathrm{T}$ transition on calf birth weight is too small to be considered on breeding programmes.

\section{ACKNOWLEDGMENTS}

This study was supported by the Financiadora de Estudos e Projetos (FINEP/ PRONEX), Fundação de Amparo à Pesquisa do Estado do Rio Grande do Sul (FAPERGS), Conselho Nacional de Desenvolvimento Científico e Tecnológico (CNPq), Pró-Reitoria de Pesquisa e Pós-Graduação da Universidade Federal do Rio Grande do Sul (PROPESQ/UFRGS), and EMBRAPA/CPPSUL. The authors wish to thank to David L. Johnson from Livestock Improvement Corporation (Hamilton, NZ) for his helpful comments on AIREML procedures.

\section{REFERENCES}

ANDERSON, S. et al. Complete sequence of bovine mitochondrial DNA. Conserved features of mammalian mitochondrial genome. Journal of Molecular Biology, v. 156, p.683-717, 1982

BARBOSA, P.F. Análise genético-quantitativa de características de crescimento e fertilidade em fêmeas da raça Canchim. 1991. 237f. Tese (Doutorado em Genética Animal) - Faculdade de Medicina de Ribeirão Preto, USP.

BELL, B.R.; MCDANIEL, B.T.; ROBINSON, O.W. Effects of cytoplasmic inheritance on production traits in dairy cattle. Journal of Dairy Science, v.68, p.2038-2051, 1985.

BOETTCHER, P.J. et al. Multiple herd evaluation of the effects of maternal lineage on yields traits of Holstein cattle. Journal of Dairy Science, v.79, p.655-662, 1996.

JOHNSON, D.L.; THOMPSON, R. Restricted maximum likelihood estimation of variance components for univariate animal models using sparse matrix techniques and average information. Journal of Dairy Science, v.78, p.449-456. 1995.

KIRKPATRICK, B.W. Genetic and biology of reproduction in cattle. In: FRIES, R; RUVINSKY, A (Eds.). The genetics of cattle. Oxon : CABI, 1999. p.391-410.

KOOTS, K.R. et al. Analysis of published genetic parameter estimates for beef production traits. 1. Heritability. Animal Breeding Abstract, v.62, p.309-338, 1994.

MAGEE, D.A. et al. A partial African ancestry for the Creole cattle population of the Caribbean. Journal of Heredity, v.93, p.429-432, 2002.

MANNEN, H. et al. Effect of mitochondrial DNA variation on carcass traits of Japanese Black cattle. Journal of Animal Science, v.76, p.36-41, 1998.

MARTIN, L.C. et al. Genetic effects on beef heifer puberty and subsequent reproduction. Journal of Animal Science, v.70, p.4006-4017, 1992.

OLIVEIRA, N.M. et al. Genetic and environmental effects on growth of 3/4 Nelore x 5/8 Aberdeen Angus beef cattle derived from different crossbreeding schemes. Archivos Latinoamericanos de Producción Animal, v.6, p.173-188, 1998.

OSORO, K.; WRIGHT, I.A. The effect of body condition, live weight, breed, age, calf performance, and calving date on reproductive performance on spring calving beef cows. Journal of Animal Science, v.70, p.1661-1666, 1992.

PEREIRA, J.C.C. Melhoramento genético aplicado à produção animal. Belo Horizonte : Fundação de Estudo e Pesquisa em Medicina Veterinária e Zootecnia, 1999. $496 \mathrm{p}$.

RORATO, P.R.N.; KEOWN, J.F.; VAN VLECK, L.D. Variance caused by cytoplasmic line and sire by herd interaction effects for milk yield considering estimation bias. Journal of Dairy Science, v.82, p.1574-1580, 1999.

SCHUTZ, M.M. et al. The effect of mitochondrial DNA on milk production and health of dairy cattle. Livestock Production Science, v.37, p.283-295, 1994.

SMITH, L.C.; ALCIVAR, A.A. Cytoplasmic inheritance and its effects on development and performance. Journal of Reproduction and Fertility: Supplement, v.48, p.3143, 1993.

STEINBORN, R.; MÜLLER, M.; BREM, G. Genetic variation in functionally important domains of the bovine mtDNA control region. Biochimica et Biophysica Acta, v.1397, p.295-304, 1998.

TESS, M.W.; MACNEIL, M.D. Evaluation of cytoplasmic geneticeffects in Miles City line-1 Hereford cattle. Journal of Animal Science, v.72, p.851-856, 1994

TROY, C.S. et al. Genetic evidence for Near-Eastern origins of European cattle. Nature, v.419, p.1088-1091, 2001.

WOLSTENHOLME, D.R. Animal mitochondrial DNA: structure and evolution. International Review of Cytology, v.141, p.173-216, 1992. 